\title{
Clostridium difficile tcdB DNA Measurement
}

National Cancer Institute

\section{Source}

National Cancer Institute. Clostridium difficile tcdB DNA Measurement. NCI Thesaurus. Code C150860.

The determination of the amount of tcdB DNA produced by Clostridium difficile present in a sample. 